\title{
The management of penetrating abdominal trauma by diagnostic laparoscopy: a prospective non-randomized study
}

\author{
Penetran karın travmalarının tanısal lapararoskopi ile yönetimi: \\ Prospektif randomize olmayan çalışma
}

\author{
Faruk KARATEKE, Mehmet ÖZDOĞAN, Sefa ÖZYAZICI, Koray DAŞ, Ebru MENEKŞE, \\ Yusuf Can GÜLNERMAN, İlhan BALİ, Safa ÖNEL, Cihan GÖKLER
}

\section{BACKGROUND}

Penetrating abdominal trauma (PAT) has been traditionally treated by exploratory laparotomy (EL). The aim of our study was to examine the use of diagnostic laparoscopy (DL) in the management of hemodynamically stable patients with PAT.

\section{METHODS}

A prospective study was performed to compare the outcomes of hemodynamically stable patients with suspected intra-abdominal injuries due to abdominal stab wounds who underwent either EL or DL. Data extracted for analysis included demographic information, operative findings, rates of non-therapeutic laparotomy, operation time, length of hospital stay, mortality, and postoperative complications.

\section{RESULTS}

Fifty-two hemodynamically stable patients were admitted to the trauma service. There were 45 male $(86.5 \%)$ and 7 female (13.5\%) patients. The average age was 34.5 years-old (1860). $26(50 \%)$ patients underwent EL, and $26(50 \%)$ patients underwent DL. Re-exploration by laparotomy was required in 9 of the 26 cases (34.6\%). Patients who underwent DL had significantly shorter hospital stays $(1.82 \pm 0.63$ days $v s$. $5.4 \pm 2.1$ days, $\mathrm{p}<0.05)$ and shorter operation time $(17.9 \pm 6.38$ vs. $68.4 \pm 33.2 \mathrm{~min}, \mathrm{p}<0.05)$ than patients who underwent $\mathrm{EL}$.

\section{CONCLUSION}

Selective use of DL in the hemodinamically stable penetrating trauma patients effectively decreased the rate of negative laparotomies, minimized morbidity, and decreased hospital stay.

Key Words: Exploratory laparotomy; diagnostic laparoscopy, penetrating abdominal trauma.

\section{$\boldsymbol{A M A C}$}

Penetran karın travmaları (PKT) geleneksel olarak tanısal laparotomi (TL) ile tedavi edilmiştir. Bu çalışmanın amacı hemodinamisi stabil olan PKT'li hastaların yönetiminde diyagnostik laparoskopi (DL) kullanımını incelemektir.

\section{GEREÇ VE YÖNTEM}

Hemodinamisi stabil olan delici-kesici alete bağlı karın içi yaralanma şüphesi nedeniyle TL veya DL yapılan hastaların sonuçları prospektif olarak kayıt edildi. Hastaların demografik özellikleri, ameliyat bulguları, hastanede kalış süresi, mortalite ve ameliyat sonrası komplikasyonları irdelendi.

\section{BULGULAR}

Hemodinamisi stabil olan 52 PKT'li hasta travma servisine alınd1. Hastaların 45'i $(\% 86,5)$ erkek, 7'si kadın $(\% 13,5)$ ve yaş ortalaması 34,5 idi (dağılım 18-60 yaş). Yirmi altı (\%50) hastaya TL, $26(\% 50)$ hastaya ise DL yap1ld. DL yapılan hastaların dokuzuna $(\% 34,6)$ laparotomi gereksinimi oldu. DL yapılan hastaların hastanede kalış süresi ve ameliyat süresi TL yapılan hastalara göre daha kısa idi (DL

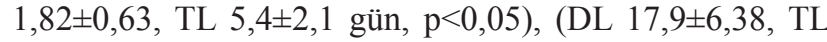
$68,4 \pm 33,2 \mathrm{dk} ., \mathrm{p}<0,05)$.

\section{SONUÇ}

Hemodinamisi stabil olan PKT'li hastalarda DL kullanımının negative laparotomi oranlarını, morbiditeyi ve hastanede kalış süresini azalttığı saptandı.

Anahtar Sözcükler: Tanısal laparotomi; diyagnostik laparoskopi; penetran karın travmasi. Adana. 
Penetrating abdominal trauma has been traditionally treated with EL. The high non-therapeutic/negative laparotomy rate and associated morbidity after EL for abdominal stab wounds led to the current selective non-operative management strategy. ${ }^{[1-2]}$ In spite of the various diagnostic methods available, diagnostic peritoneal lavage (DPL), focused abdominal sonography for trauma (FAST), and computed tomography (CT), it is difficult to determine the presence and severity of intra-abdominal injuries caused by abdominal stab wounds. EL is the most popular procedure for definitive evaluation of patients sustaining penetrating abdominal trauma (PAT), which carries a $0-5 \%$ mortality rate, a $20 \%$ morbidity rate, and a $3 \%$ long term risk of bowel obstruction. ${ }^{[3]}$ However, more recent reports have shown that $30-50 \%$ of all stab wounds do not penetrate the peritoneum and another $20-40 \%$ with peritoneal penetration do not involve significant injuries, resulting in non-therapeutic laparotomy rates as high as $70 \%{ }^{[1,4]}$ Laparoscopy has recently been safely used for PAT patients for diagnostic and therapeutic purposes, avoiding unnecessary laparotomies, shortening the length of hospital stay, and reducing medical costs. ${ }^{[5,6]}$

The aim of our study was to examine the use of diagnostic laparoscopy (DL) in the management of hemodynamically stable trauma patients with penetrating anterior abdominal injuries.

\section{MATERIALS AND METHODS}

We performed a prospective study to compare the outcomes of hemodynamically stable patients with suspected intra-abdominal injuries from abdominal stab wounds who underwent either EL or DL. Fiftytwo hemodynamically stable patients with abdominal stab wounds, admitted to Adana Numune Training and Research Hospital over the 1-year period between June, 12010 and July, 12011 were included in the study. Our center serves as a level 1 trauma center for a district of 3 million residents. Critically injured patients are either transported directly to our center by the emergency medical service or are transferred from local community hospitals after initial management. The Ethical Committee of our center approved the study protocol.

Patients with stab wounds located at the flank or back, patients with no penetration of the peritoneum at local wound exploration, and patients who were operated on immediately due to peritonitis, shock, or evisceration of organs on admission were excluded from this study. Our clinical algorithm for abdominal stab wounds is shown on Fig. 1.

All procedures were performed in the operating room under general anesthesia and all patients consented to possible conversion to laparotomy. After induction of general anesthesia, Foley catheter and orogastric or nasogastric tubes were placed in each patient. Tube thoracostomy was performed before laparoscopy when chest radiography showed hemo/ pneumothorax. An umbilical trocar was placed by the Hasson technique and the abdomen was insufflated with $\mathrm{CO}_{2}$ to a pressure of $15 \mathrm{mmHg}$. A $30^{\circ} 10-\mathrm{mm}$ laparoscope was used initially in all patients. Additional 5-mm ports were placed under direct vision as necessary for manipulation of the bowel. All quadrants were carefully inspected and the small bowel and colon were examined. Lavage samples were sent for Gram staining in order to detect possible bowel injuries. All EL were performed using a standard midline incision under general anesthesia. The operative procedure was performed by one of seven surgeons who were experienced in emergency laparoscopy and laparotomy.

\section{Definitions}

Relative to penetrating injuries, several definitions are required for findings of both laparoscopy and laparotomy procedures. Negative laparoscopy was defined as the presence of peritoneal penetration but no intra-abdominal injury. Non-therapeutic laparoscopy is the presence of organ injury that did not require intervention. Therapeutic laparoscopy is a procedure in which the organ injury was managed laparoscopically. Re-exploration by laparotomy defines a laparoscopic exploration followed by laparotomy. Negative laparotomy was the absence of intra-abdominal injury. Non-

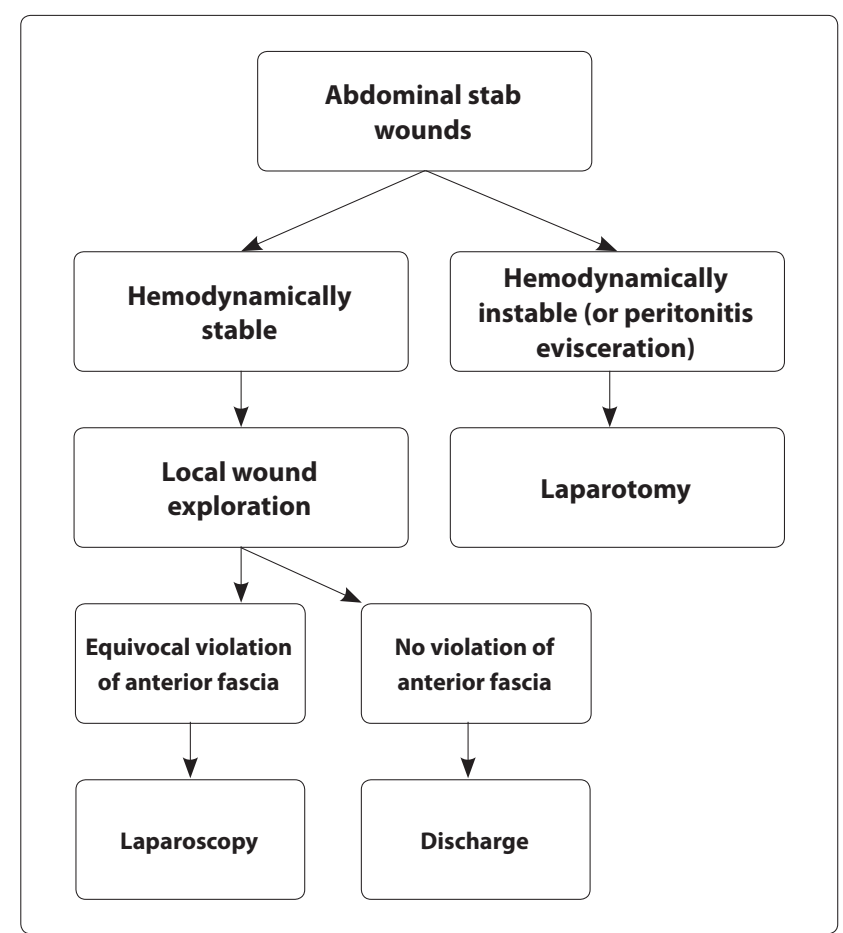

Fig. 1. Our algorithm for the evaluation of abdominal stab wounds. 
Table 1. Demographic characteristics, hemodynamic parameters in emergency room, and laboratory findings of hemodynamically stable patients with suspected abdominal injuries

\begin{tabular}{lccc}
\hline & $\begin{array}{c}\text { Exploratory laparotomy }(\mathrm{n}=35) \\
\text { Mean } \pm \text { SD }\end{array}$ & $\begin{array}{c}\text { Diagnostic laparoscopy }(\mathrm{n}=17) \\
\text { Mean } \pm \text { SD }\end{array}$ \\
\hline Gender (Male / Female) & $30 / 5$ & $15 / 2$ & 0.512 \\
Age & $35.2 \pm 10.6$ & $33.2 \pm 9,2$ & 0.142 \\
Initial SBP (mmHg) & $107.0 \pm 12.3$ & $112.3 \pm 11.8$ & 0.390 \\
Initial HR (beats/min) & $94.8 \pm 12.2$ & $91.7 \pm 12.0$ & $<\mathbf{0 . 0 0 0 1}$ \\
Hematocrit & $38 \pm 6.6$ & $42.9 \pm 2.0$ & 0.342 \\
Multiple stab wounds (\%) & $20(7 / 35)$ & $11.7(2 / 17)$ &
\end{tabular}

Data are presented a mean \pm standard deviation (SD) or number and percentage. SBP: Systolic blood pressure; HR: Heart rate.

therapeutic laparotomy found organ injury that did not require intervention. Therapeutic laparotomy required surgical treatment of organ injury.

\section{Data collection and statistical analysis}

Data extracted for analysis included demographic information, hemodynamics in the emergency room, operative findings, operative techniques, rates of significant injuries, rates of non-therapeutic laparotomy, operation time, length of hospital stay, hospital mortality, and postoperative complications. Statistical significance $(p<0.05)$ was determined by the chi-square test (or Fisher's exact test when $\mathrm{n}<5$ ) for categorical data, and the Mann-Whitney U-test for continuous variables.

\section{RESULTS}

There were 45 male $(86.5 \%)$ and 7 female $(13.5 \%)$ patients. The average age was 34.5 years-old (18-60). Locations of the stab wounds were: anterior abdomen in $36(69 \%)$ patients and the thoracoabdominal region in $16(31 \%)$. Focused abdominal sonography for trauma (FAST) was positive in 11 patients and computerized tomography (CT) was positive in 1 patient. Table 1 shows the demographic characteristics and hemodynamic and laboratory parameters of the patients. The peritoneal violation rate was $100 \%$.

Of the total 52 patients included in the study, 26 $(50 \%)$ patients underwent EL, and $26(50 \%)$ patients underwent DL. Re-exploration by laparotomy was required in 9 of the 26 cases $(34.6 \%)$, which resulted in therapeutic operation for 8 patients, with a non-therapeutic laparotomy for 1 of the 9 cases. That special case was converted to laparotomy because of false positive lavage performed during DL, which revealed Gr. (-) bacteria. Re-exploration by laparotomy was performed for one patient due to intrabdominal abscess detected 3 days after DL. In that case, the abscess was considered to have occurred due to the contamination of washing saline during DL. Re-exploration by laparotomy was performed in 3 patients for small bowel injury, 2 patients for splenic injury and in 2 patients for
Table 2. The operative procedures of the patients admitted with penetrating abdominal trauma

\begin{tabular}{lcc}
\hline Procedure & $\mathrm{n}$ & $\%$ \\
\hline Exploratory laparotomy $(\mathrm{n}=26,50 \%)$ & & \\
$\quad$ Negative/nontherapeutic & 13 & 25 \\
$\quad$ Therapeutic & 13 & 25 \\
Diagnostic laparoscopy $(\mathrm{n}=17,32.7 \%)$ & & \\
$\quad$ Negative/nontherapeutic & 13 & 25 \\
$\quad$ Therapeutic & 4 & 7.7 \\
Re-exploration by laparotomy $(\mathrm{n}=9,17.3 \%)$ & & \\
$\quad$ (Laparoscopy / Laparotomy) & & \\
$\quad$ Negative/nontherapeutic & 1 & 1.9 \\
$\quad$ Therapeutic & 8 & 15.3 \\
\hline
\end{tabular}

gastric injury. Therapeutic laparoscopy was performed in 4 patients. In one patient diaphragmatic injury was repaired and hemostasis of mesenteric and omental bleeding sources were achieved in another 3 patients. The surgical procedures performed for PAT patients are shown in Table 2.

Seventeen $(32.7 \%)$ patients were evaluated by laparoscopy (group 1) and a total of $35(67.3 \%)$ patients underwent laparotomy eventually (group 2). There were no significant differences between the demographic characteristics, hemodynamic parameters and laboratory findings in the emergency room between patients in the two groups. Patients in group 1 had a significantly shorter hospital stay $(1.82 \pm 0.63$ days $v s$. $5.4 \pm 2.1$ days, $\mathrm{p}<0.05$ ) (Fig. $2 \mathrm{a}$ ) and shorter operation time (17.9 \pm 6.38 vs. $68.4 \pm 33.2$ minutes, $\mathrm{p}<0.05$ ) (Fig. $2 b)$ than patients in group 2 . The rate of unnecessary laparotomies in group 2 was $40 \%$.

Negative/non-therapeutic laparotomy was performed on 13 patients and negative/nontherapeutic laparoscopy was performed on 13 patients. Patients who underwent negative /non-therapeutic laparoscopy had a significantly shorter operation time and shorter hospital stay than patients who underwent negative/ non-therapeutic laparotomy. There was no significant difference in ICU stay between groups. There was one 


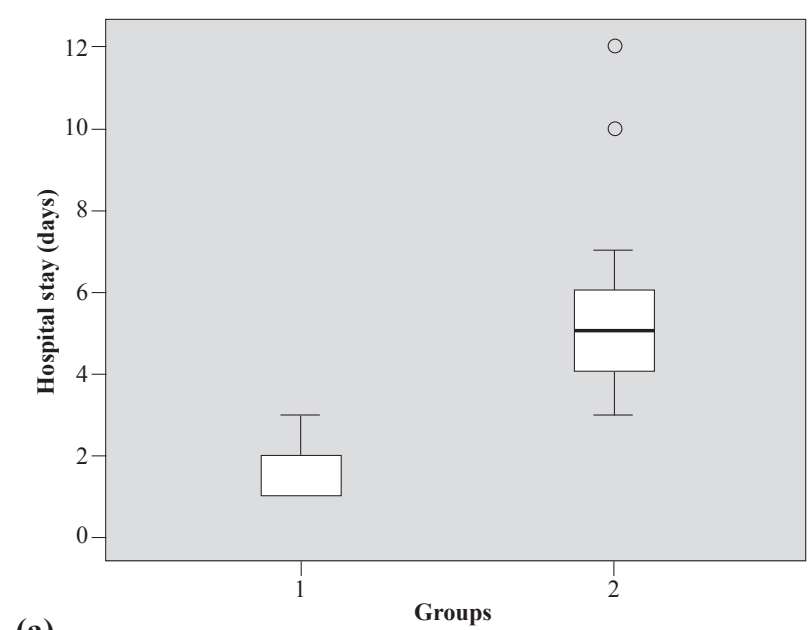

(a)

Fig. 2. (a) Comparison of hospital stay between the groups. (b) Comparison of operation time between the goups.

complication among negative /non-therapeutic laparoscopy patients, although 5 patients had complications after negative/non-therapeutic laparotomy. Complications included wound infection in 4 patients and pneumonia in 1 patient (Table 3).

Overall sensitivity for intra-abdominal injuries using DL was $92.3 \%$, and specificity was $100 \%$ for penetrating abdominal trauma in hemodinamically stable patients. Similarly, positive predictive and negative predictive values for intra-abdominal injuries were $100 \%$ and $92.9 \%$, respectively. Sensitivity of DL for any therapeutic intervention was calculated as $88.9 \%$.

\section{DISCUSSION}

The aim of our study was to assess the overall benefits of DL in the evaluation of stable patients with abdominal stab wounds. Emergency department evaluation of the injured patient has evolved greatly over the years, mainly due to the advances in imaging technology. Trauma surgeons have a variety of diag-

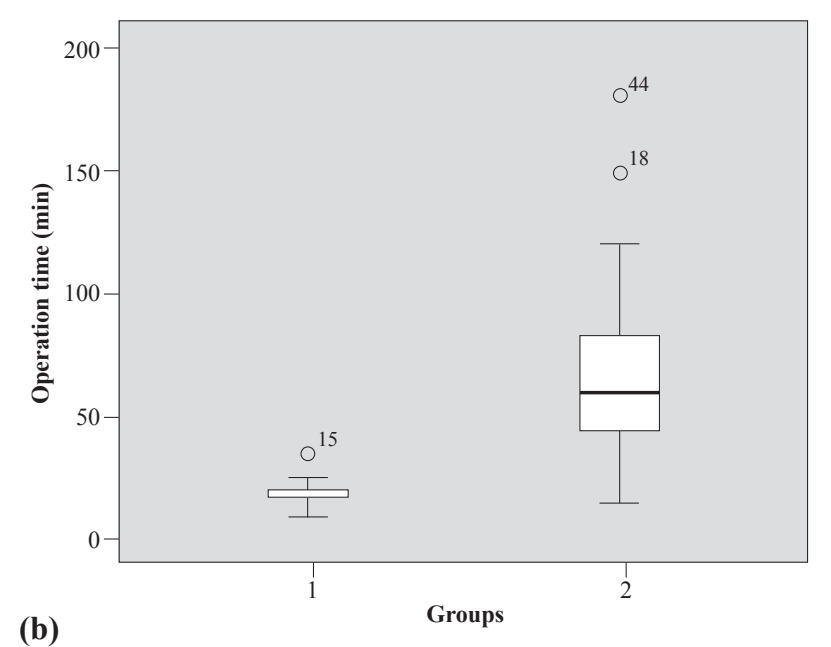

(b)

nostics tools to assist with the management of their patients, including observation with serial physical examination, DPL, FAST, and CT. Each of these modalities has strengths and weaknesses that must be considered and none are $100 \%$ reliable. For this reason, EL is often performed in the case of stab wounds, but EL in trauma patients is associated with a high negative laparotomy rate, and procedure-related morbidity can reach up to $40 \%{ }^{[2]}$

The increased availability of laparoscopy now offers even more flexibility during the workup of injured patients. Diagnostic laparoscopy has been proposed for trauma patients to prevent unnecessary exploratory laparotomies with associated higher morbidity and cost. ${ }^{[6]}$

In a review by Villavicencio and Aucar, DL for penetrating trauma reported had sensitivity of 80 $100 \%$, specificity of $38-86 \%$, and accuracy of $54-$ $89 \% .{ }^{[7]}$ In another study conducted by Ertekin et al. ${ }^{[8]}$ the specificity and sensitivity of DL were $100 \%$ in

Table 3. Comparison of negative/nontherapeutic laparoscopy and negative/nontherapeutic laparotomy patients

\begin{tabular}{lccc}
\hline & Negative/nontherapeutic laparotomy & Negative/nontherapeutic laparoscopy & $p$ \\
\hline Operating time (min) & $55.77 \pm 18.46$ & $18.08 \pm 6.6$ & $<\mathbf{0 . 0 0 0 1}$ \\
ICU stay & $1.00 \pm 0.00$ & $1.00 \pm 0.00$ & $>\mathbf{0 . 0 0 5}$ \\
Hospital stay (days) & $3.69 \pm 0.85$ & $1.77 \pm 0.59$ & $\mathbf{0 . 0 0 0 1}$ \\
Complication & $5(38.4 \%)$ & $1(7.6 \%)$ & 0.047 \\
Insignificant injuries & & & \\
$\quad$ Liver & 3 & 3 & \\
$\quad$ Omentum & 4 & 1 & \\
$\quad$ Spleen & 2 & 4 & \\
No organ injury & 3 & & \\
\hline
\end{tabular}

Data are presented a mean \pm standard deviation (SD) or number and percentage. 
lower thoracic penetrating trauma. The positive diagnostic value and negative predictive value for peritoneal penetration were found to be $100 \%$. Laparoscopy can prevent laparotomy in $63 \%$ of patients with a variety of injuries. ${ }^{[7]}$ The laparoscopic approach avoids negative laparotomy in $23-54 \%$ of patients with stab wounds and blunt abdominal trauma. Laparoscopy is more cost-effective than negative laparotomy. ${ }^{[7]}$

DeMaria et al. ${ }^{[9]}$ compared mandatory celiotomy to laparoscopy in hemodynamically stable patients with thoracoabdominal stab wounds. Non-therapeutic laparotomy was significantly less common in the group initially evaluated by laparoscopy (19\% vs. $57 \%)$. The sensitivity, specificity and accuracy of laparoscopic evaluation were also superior when compared to DPL in predicting the need for therapeutic intervention at open abdominal exploration. We performed DPL during DL procedure in some of our patients in order to rule out possible hollow viscus injuries.

In our study, patients who underwent DL had shorter hospital stays and shorter operation time than patients who underwent EL. The rate of unnecessary laparotomies was $40 \%$. In our study group, DL could potentially decrease the rate of unnecessary laparotomy as a figure of $59.6 \%$ if applied to all patients.

Sensitivity of DL was $92.3 \%$, and specificity was $100 \%$ in our study. Similarly, positive predictive and negative predictive values for intra-abdominal injuries were $100 \%$ and $92.9 \%$, respectively. Sensitivity of DL for any therapeutic intervention was $88.9 \%$.

Similarly, patients who underwent negative/nontherapeutic laparoscopy had a significantly shorter operation time and shorter hospital stay than patients who underwent negative/non-therapeutic laparotomy. There was no significant difference in ICU stay between groups. There was one complication among negative/non-therapeutic laparoscopy patients, and 5 patients had complications after negative/nontherapeutic laparotomy.

The opinion in the early 1990s, supported by published data, that there was a higher incidence of complications with laparoscopy is now outdated due to increasing experience and technical improvements. Procedure-related complications occur in up to $11 \%$ of patients and are usually minor (level I-III). ${ }^{[10]}$ A 1999 review of 37 studies, which included more than 1,900 patients, demonstrated a procedure-related complication rate of $1 \%{ }^{[7]}$ Recent studies have reported a median of $0 \%$ (range $0-10 \%$ ) procedure-related morbidity and $0 \%$ mortality (level I-III). Intraoperative complications can occur during creation of the pneumoperitoneum, trocar insertion, or during the diagnostic examination. ${ }^{[10]}$ Similar to the literature, procedure-related complication rate due to DL was $7.6 \%$ in our study.
Although we currently use the laparoscope as a screening tool for peritoneal penetration, the next logical progression is to conduct a more effective laparoscopic treatment of specific organs in the trauma setting. This could potentially decrease or eliminate the number of non-therapeutic conversion from laparoscopy to laparotomy. The threshold for conversion would vary among surgeons based on laparoscopic expertise and confidence in the laparoscopic examination. The next step is to increase therapeutic intervention as we gain more experience.

Selective use of DL in penetrating trauma patients effectively decreases the rate of negative laparotomies and minimizes patient morbidity and hospital stay, with its high sensitivity, specificity, positive and negative predictive values. To optimize results, this procedure should be incorporated in institutional diagnostic and treatment algorithms for trauma patients.

Conflict-of-interest issues regarding the authorship or article: None declared.

\section{REFERENCES}

1. Selman U, Katrin D. Laparoscopy in abdominal trauma. Eur J Trauma Emerg Surg 2010;36:19-24.

2. Leppaniemi A, Salo J, Haapiainen R. Complications of negative laparotomy for truncal stab wounds. J Trauma 1995;38:54-8.

3. Shih HC, Wen YS, Ko TJ, Wu JK, Su CH, Lee Ch. Noninvasive evaluation of blunt abdominal trauma: Prospective study using diagnostic algorithms to minimize nontherapeutic laparotomy. World J Surg 1999;23:265-70.

4. Fabian TC, Croce MA, Stewart RM, Pritchard FE, Minard G, Kudsk KA. A prospective analysis of diagnostic laparoscopy in trauma. Ann Surg 1993;217:557-65.

5. Zantut LF, Ivatury RR, Smith RS, Kawahara NT, Porter JM, Fry WR et al. Diagnostic and therapeutic laparoscopy for penetrating abdominal trauma: a multicenter experience. J Trauma 1997;42:825-31.

6. Taner AS, Topgul K, Kucukel F, Demir A, Sari S. Diagnostic laparoscopy decreases the rate of unnecessary laparotomies and reduces hospital costs in trauma patients. J Laparoendosc Adv Surg Tech 2001;11:207-11.

7. Villavicencio RT, Aucar JA. Analysis of laparoscopy in trauma. J Am Coll Surg 1999;189:11-20.

8. Ertekin C, Onaran Y, Güloğlu R, Günay K, Taviloğlu K. The use of laparoscopy as a primary diagnostic and therapeutic method in penetrating wounds of lower thoracal region. Surg Laparosc Endosc 1998;8:26-9.

9. DeMaria EJ, Dalton JM, Gore DC, Kellum JM, Sugerman HJ. Complimentary role of laparoscopic abdominal exploration and diagnostic peritoneal lavage for evaluating abdominal stab wounds: a prospective study. J Laparoendoscopic Adv Surg Techniques 2000;10:131-6.

10. Hori Y; SAGES Guidelines Committee. Diagnostic laparoscopy guidelines : This guideline was prepared by the SAGES Guidelines Committee and reviewed and approved by the Board of Governors of the Society of American Gastrointestinal and Endoscopic Surgeons (SAGES), November 2007. Surg Endosc 2008;22:1353-83. 